\title{
Investigation of Short-wave Diathermy Genotoxic Effect in Patients with Knee Osteoarthritis
}

\author{
Diz Osteoartriti Olan Hastalarda Kısa Dalga Diaterminin Genotoksik Etkisinin \\ Araştırılması
}

\author{
(D) Önder Şener, (D) Sami Hizmetli*, (D) Ahmet Karadağ*, (D) Emrullah Hayta** \\ Antakya State Hospital, Clinic of Physical Medicine and Rehabilitation, Hatay, Turkey \\ ${ }^{*}$ Cumhuriyet University Faculty of Medicine, Department of Physical Medicine and Rehabilitation, Sivas, Turkey \\ **Kadıköy Acıbadem Hospital, Clinic of Physical Medicine and Rehabilitation, Istanbul, Turkey
}

\section{Abstract}

Objective: Short-wave diathermy (SWD) is a physical therapy agent that is commonly used as a deep heater in physical medicine practices. The aim of this study was to investigate whether there is a chromosomal damage arising from therapeutic SWD by using micronucleus (MN) method.

Materials and Methods: Thirty patients who suffered from knee pain, and diagnosed as gonarthrosis according to American College of Rheumatology criteria were admitted in the present study. Twenty patients were assigned as the treatment group (group 1) and 10 patients were assigned as the control group (group 2). The patients in the treatment group received 10 sessions of SWD therapy, whereas the patients in the control group received 10 sessions of sham SWD therapy. Peripheral venous blood was obtained from both the treatment and the control groups before and after 10 sessions of SWD therapy to evaluate MN scores. The scores of MN assessed before the therapy were compared with the MN scores at the end of 10 sessions of SWD therapy in the treatment and the control groups. Pre-treatment and end of the $10^{\text {th }}$ session $\mathrm{MN}$ scores were compared between the treatment and the control groups.

Results: There was not a statistically significant difference in MN scores between pre-treatment and after $10^{\text {th }}$ session SWD therapy in both groups ( $p>0.05$ ). There was also not a significant difference in the MN scores of the groups between pre-treatment and after $10^{\text {th }}$ session of SWD therapy ( $p>0.05)$.

Conclusion: In this study, we observed that the therapeutic SWD did not induce an increase in MN score, which is a sign of cytogenetic damage.

Keywords: Short-wave diathermy, micronucleus assay, gonarthrosis

\section{$\ddot{O z}$}

Amaç: Kısa dalga diatermi (KDD), fiziksel tıp uygulamalarında genellikle derin ısıtıcı olarak kullanılan bir fizik tedavi ajanıdır. Bu çalışmanın amacı, terapötik KDD'den kaynaklanan bir kromozomal hasar olup olmadığını mikronükleus (MN) yöntemiyle araştırmaktır.

Gereç ve Yöntem: Çalışmaya diz ağrısı olan ve Amerikan Romatoloji Koleji kriterleri ile gonartroz tanısı alan 30 hasta dahil edildi. Yirmi hasta tedavi grubu (grup 1), 10 hasta kontrol grubu (grup 2) olarak tayin edildi. Tedavi grubundaki hastalara 10 seans KDD tedavisi uygulandı, kontrol grubundaki hastalara ise 10 seans sahte KDD tedavisi uygulandı. MN skorlarını değerlendirmek için periferik venöz kan, hem tedavi hem de kontrol grubundan 10 seans KDD tedavisi uygulaması öncesi ve sonrasında alındı. Tedavi öncesi değerlendirilen MN skorları, tedavi grubunda ve kontrol gruplarında 10 seans KDD tedavisi sonu MN skorları ile karşılaştıııldı. Tedavi öncesi ve 10 seans KDD tedavi sonrası MN skorları tedavi ve kontrol grubu arasında karşılaştııılı.

Bulgular: Her iki grubun KDD tedavisi öncesi ile 10 seans KDD tedavisi sonrasında MN skorları arasında istatistiksel olarak anlamlı bir fark yoktu ( $p>0,05)$. Grupların MN skorları karşılaştııılı̆̆ında KDD tedavisi öncesi ve 10 seans KDD tedavisi sonrasında MN skorları açısından gruplar arasında anlamlı bir fark yoktu $(p>0,05)$.

Sonuç: Bu çalışmada, terapötik KDD’nin, sitogenetik hasarın bir işareti olan MN skorunda artışa neden olmadığını gözlemledik.

Anahtar kelimeler: Kısa dalga diatermi, mikronükleus deneyi, gonartroz

Address for Correspondence/Yazıșma Adresi: Ahmet Karadağ MD, Cumhuriyet University Faculty of Medicine, Department of Physical Medicine and Rehabilitation, Sivas, Turkey Phone: +90 5065335456 E-mail: dr_ahmetkaradag@hotmail.com ORCID ID: orcid.org/0000-0002-5284-2256 Received/Geliş Tarihi: 24.02.2019 Accepted/Kabul Tarihi: 30.04.2019

${ }^{\circ}$ Copyright 2019 by the Turkish Osteoporosis Society

Turkish Journal of Osteoporosis published by Galenos Publishing House. 


\section{Introduction}

Short-wave diathermy (SWD) is used by physical therapists to treat symptoms of osteoarthritis and this treatment's one of the oldest forms of electrotherapeutic modalities traditionally (1). SWD is a high frequency current which leads to heat increases into the deep tissues by means of the conversion of electromagnetic energy into thermal energy. In medicine, generally the form of SWD, which has $27.12 \mathrm{MHz}$ frequency and 11 wavelengths, is used (2). Along with microwaves, infrared radiation and laser beams, SWD radio waves are categorized into the non-ionized radiation (NIR) group. Like ionized radiation (X-ray), high density NIR does not affect the molecular structure of the cells. SWD can lead to heat increase in the tissues, alterations in the chemical reactions or to the induction of electrical currents in the cells and the tissues. While SWD poses minimal heat increases in the skin and subcutaneous tissues, it can lead to maximal heat increases in deep tissues like muscles and bones (3-5). SWD is in the NIR group; however, it has been mentioned that their usage in medical treatment in different doses and lengths may lead to potential detrimental effects on the biological tissues (6).

Because radio frequency/microwave radiation leads to increases in DNA strand breaks and the amount of reactive oxygen, the studies on cell cultures, human blood and rats have shown that it increases tendency to brain cancer or neurodegenerative diseases $(7,8)$. In order to detect the chromosomal damage, cytogenetic tests such as micronucleus (MN) assay, chromosomal aberrations are used. MN assay is rapid, simple and sensitive test. Additionally, there is a direct correlation between gene damage and $\mathrm{MN}$ frequency $(9,10)$. According to our knowledge, among the studies related to high frequency currents, presently, there is no study conducted to investigate the genotoxic damage of SWD and similar high frequency currents, their side effects related to the extended exposure to these agents and the treatment dose. The aim of the study was to investigate the genotoxic effect of SWD with MN assay.

\section{Materials and Methods}

\section{Case Selection}

The approval of Human Ethics Committee of our university and informed consent was obtained from all the participants (2008-4/7). The study was conducted in accordance with the principles of the Declaration of Helsinki. During the study period, 30 consecutive patients who clinically meet ACR's knee osteoarthritis diagnosis criteria (11) were identified suitable for the study. Twenty patients were selected as treatment group, ten patients were selected as controls. Exclusion criteria were smoking, use of alcohol, history of viral illness in the last month, and history of medical therapy, chemotherapy, radiotherapy, ultrasonography, X-Ray, magnetic resonance imaging, or shortwave therapy.

\section{Physical Therapy Program}

In order to prevent possible effects of surface heaters, electrotherapy, and analgesic and muscle relaxant drugs on MN, only SWD therapy is applied to the study participants as physiotherapy. SWD therapy is applied to same region and the same therapy protocol is applied on all cases in order to prevent differences that may arise from application region, the dose of SWD and duration of SWD. SWD therapy is applied on the patients while they were sitting and sprawling their legs out on their bed. During the application their legs have been supported with rolls beneath and held in 10 degrees slight flexion. Therapy is applied with $12 \mathrm{~cm}$-diameter electrodes that have been located bilaterally and parallel on knees and with enraf nonius curapuls 419 ( $f=27.12 \mathrm{MHz}, p=400$ Watt) device in continuous mode and thermal dose as 10 sessions of 30 minutes (2 weeks with 5 days per week and 1 session daily). Therapies are always applied by the same physiotherapist with the same device and in the same hour every day. Sham therapy is applied for 30 minutes on the knees of cases that are in the control group and electromagnetic energy hasn't been given. Peripheral venous blood has been taken from patients in the therapy and control groups before and after 10 session therapy, using $5 \mathrm{~mL}$ sterile syringes that contain 0.1-0.2 $\mathrm{mL}$ heparin. Blood samples were analyzed in our Genetics Laboratory immediately after being received in order to perform lymphocyte cell culture.

\section{Lymphocyte Culture}

Culture has been prepared in sterile medium by adding $1 \mathrm{~mL}$ peniciline-streptomycine into $100 \mathrm{Ml}$ Karyotyping MediumPB and slowly mixing by hand. Prepared medium has been divided into $5 \mathrm{~mL}$-volume screw cap-conic base culture tubes and stored by freezing in $-20{ }^{\circ} \mathrm{C}$ after waiting in laboratory for 10-15 minutes.

\section{Micronucleus Assay}

According to the method of Fenech and Morley, cytochalasin-B (Sigma Chemical Co., St. Louis, MO, USA) was added to cultures to give a final concentration of $3 \mathrm{mcg} / \mathrm{mL}$, at 44 hours of incubation (12). With the method of Balasem AN and Ali AS (13) the cultures were stopped at 72 hours, treated with hypotonic solution $(0.1 \mathrm{~mol} / \mathrm{L} \mathrm{KCl})$ for $3 \mathrm{~min}$ and fixed to two changes of methanol-acetic acid (3:1). The fixed cells were spread onto glass slides and colored with $5 \%$ Giemsa for $7 \mathrm{~min}$. All the slides were marked and read "blind." Different slides of two parallel cultures of one person were prepared to detect intra-individual differences. Bin binucleated cells were analyzed for each case by the searching $(13,14)$ published citeria for micronuclei determinations. Figure 1 shows normal dual-core micronucleated cells.

\section{Statistical Analysis}

All data analyses were carried out using SPSS (version 22.0) software (SPSS Inc., Chicago, IL, USA). Continuous data was expressed as mean \pm standard deviation and categorical data was expressed as a percentage (\%). The normal distribution 


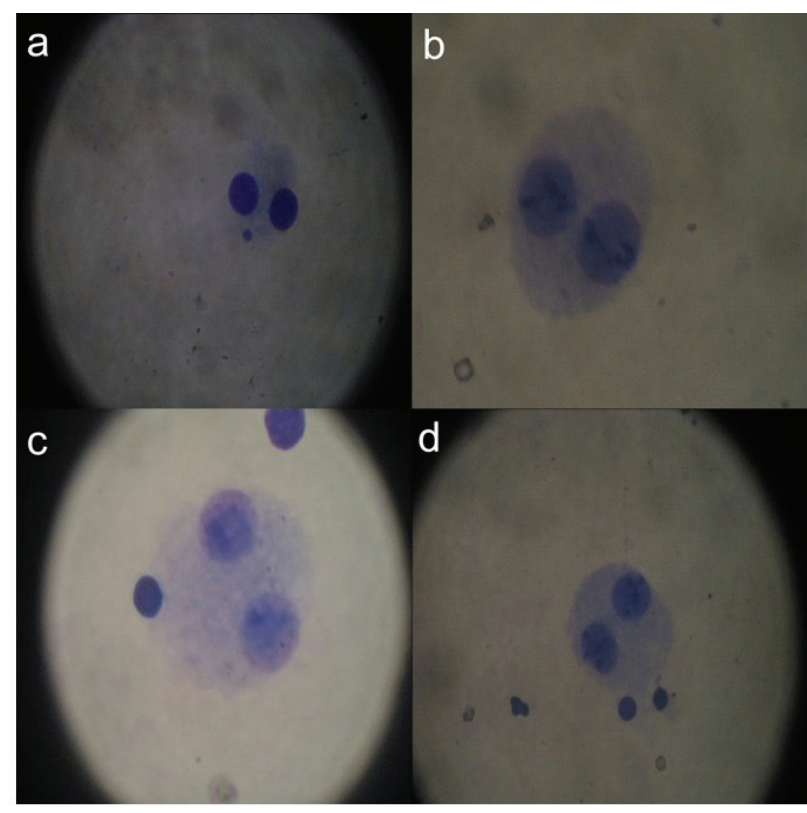

Figure 1. a) Normal dual-core, b) and, c) Dual-core micronucleated cells, d) MN cells containing two dual-core MN: Micronucleus

of the data was analyzed using Shapiro-Wilk test. Age and gender were compared with $t$ and chi-square tests, respectively. MN frequency was analyzed with paired or unpaired t-test as appropriate. A p value less than 0.05 were considered as significant. The confidence level of the study and the prevalence of the disease was accepted as $95 \%$ and $23.9 \%$, respectively (15). Accordingly 20 individuals were included in the patient group under treatment, and the power of the study was calculated as $81.31 \%$. [n=(p.q.t2)/d2]

\section{Results}

All the patients and controls were completed the study. The patients and controls were similar with regard to the female ratio (14/20 vs $7 / 10)$ and age (44.2 \pm 5.2 vs $44.0 \pm 5.8$ years) ( $p>0.05)$.

Figure 2 presents the MN frequency of patients and controls, measured as pretreatment and post treatment. In both patients and controls, there was no significant difference between pretreatment and post treatment $M N$ frequencies ( $p>0.05$ ). There were no significant differences between the patients and controls with regard to both pretreatment and post treatment MN frequencies ( $p>0.05)$.

\section{Discussion}

In this study, we assessed the genotoxic effect of SWD before and after treatment in osteoarthritis patients and healthy controls and found that SWD did not cause any meaningful genotoxic effect as demonstrated by MN assay.

MN are extra nuclear units containing damaged chromosome fragments and/or whole chromosomes removed from the

\section{- Pretreatment}

๑ Postreatment

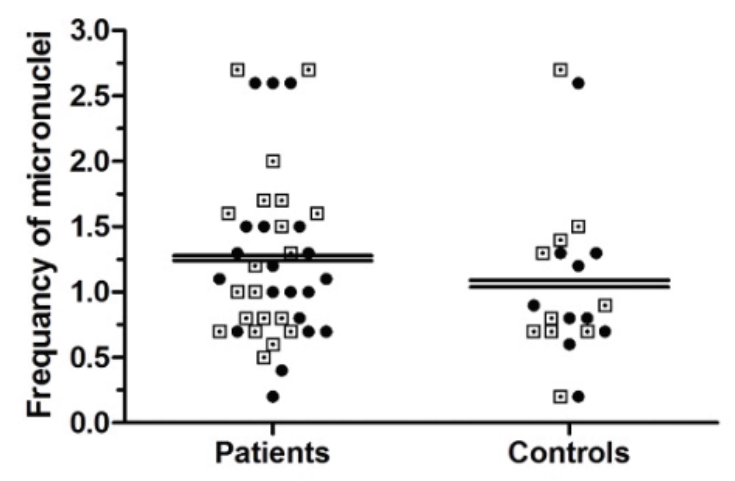

Figure 2. Pretreatment and posttreatment MN frequency of study groups. Dots present the MN frequency of subjects in study groups. Lines present mean MN frequency of study groups, measured as pretreatment ad posttreatment. After paired and unpaired comparisons, there were no significant differences MN: Micronucleus

nucleus after cell division (16). MN may be the result of abnormal function of cell repair mechanisms and accumulation of DNA damages and chromosomal errors. Several genotoxic agents for their effects on the MN formation leading to cell death, genomic instability, or cancer development were studied (17). The potential of ionizing radiation to damage DNA directly or indirectly is a good example of such genotoxic effect. To alter the DNA structure and influence nuclear integrity different genotoxic agents have many different ways (18). Usually they are divided into two classes according to the mechanism of action: clastogens causing breaks in chromosomes, and aneugens affecting cell division and mitotic spindle apparatus, leading to aneuploidy. MN may be formed as a result of clastogenic or aneugenic exposures, their effects alter the content of the MN as clastogens and aneugens will form MN with acentric fragments and all chromosomes one by one (19). In recent years, there has been an increasing interest and many clinical studies on the effects of electromagnetic field radiating from SWD equipments on the people who are exposed to these fields (20-24). Although there is a general consensus on the fact that RF radiation waves are not directly mutagenic, some studies reveal the mutagenic effects of the RF waves. In these positive findings, mutagenic effects are suggested to be related to the type of the RF waves and their modulation (25).

In the studies investigating the genotoxic effects of SWD, animals were commonly used instead of humans and in vitro studies were preferred rather than in vivo studies. The studies about the genotoxic effects of SWD on humans generally focus on its negative on the pregnancy results of the women physiotherapists. In these studies, it has been revealed that SWD has potential detrimental effects on the pregnancy results such as low birth weight, congenital malformation and an increase in perinatal death risk (26-29). In a study investigating 
the pregnancy in rats, it was found that high RF application is teratogenic in rats during the gestation period. It was thought that the effects observed in the treated rats were related to the hypothermia caused by RF (30).

To the knowledge of the researchers, in the literature, there is no study about SWD and other high frequency currents investigating the emerging side effects of long-term exposure to these agents, the treatment dose and genotoxic effect of SWD applications throughout the treatment.

Nowadays, MN assay provides the most prevalent biomarker of chromosomal defects induced by genotoxic agents due to their rapid formation and easy detection in laboratory practice. MN formation is accepted as related to the initial stage in the development of genomic instability and tumor genesis. Although MN investigations are gaining importance in the literature, there are important knowledge gaps needing new studies as both on most effective ways of MN detection and agents causing MN formation. In clinical practice, several treatment modalities like SWD are used during the management of musculoskeletal disorders.

\section{Study Limitation}

The limitation of the present study is the limited number of patients and control group.

\section{Conclusion}

In the present study, in a clinical settings of SWD administration as continuous mode and thermal dose as 10 sessions of 30 minutes ( 2 weeks with 5 days per week and 1 session daily), SWD has no genotoxic effect in patients with osteoarthritis. However, because of the somewhat conflicting results of the in vitro and in vivo studies conducted on the electromagnetic radiation agents (such as radar, microwave), further studies are needed to expand knowledge related the genotoxic effects of SWD in patients with several musculoskeletal disorders. These studies may increase the safety profile of SWD and their use by physiatrists and physiotherapist.

\section{Ethics}

Ethics Committee Approval: The approval of Human Ethics Committee of our university and informed consent was obtained from all the participants (2008-4/7).

Informed Consent: Informed consent was obtained from all the participants.

Peer-review: Internally peer-reviewed.

\section{Authorship Contributions}

Surgical and Medical Practices: Ö.Ş., S.H., Concept: Ö.Ş., S.H., Design: Ö.Ş., S.H., Data Collection or Processing: Ö.Ş., A.K., E.H., Analysis or Interpretation: Ö.Ş., A.K., E.H., Literature Search: Ö.Ş., S.H., A.K., E.H., Writing: Ö.Ş., S.H., A.K., E.H.

Conflict of Interest: The authors declare that they have no conflict of interest.

Financial Disclosure: The authors declared that this study received no financial support.

\section{References}

1. Wang H, Zhang C, Gao C, Zhu S, Yang L, Wei Q, et al. Effects of short-wave therapy in patients with knee osteoarthritis: a systematic review and meta-analysis. Clin Rehabil 2017;31:66071.

2. Zeng C, Gao SG, Lei GH. Comment on Laufer et al. entitled "Effectiveness of thermal and athermal short-wave diathermy for the management of knee osteoarthritis: a systematic review and meta-analysis". Osteoarthritis Cartilage 2014:22:605-6.

3. Incebiyik S, Boyaci A, Tutoglu A. Short-term effectiveness of short-wave diathermy treatment on pain, clinical symptoms, and hand function in patients with mild or moderate idiopathic carpal tunnel syndrome. J Back Musculoskelet Rehabil 2015;28:221-8.

4. Al-Mandeel MM, Watson T. The thermal and nonthermal effects of high and low doses of pulsed short wave therapy (PSWT). Physiother Res Int 2010;15:199-211.

5. Israel M, Zaryabova V, Ivanova M. Electromagnetic field occupational exposure: non-thermal vs. thermal effects. Electromagn Biol Med 2013;32:145-54.

6. Lehman JF, De Lateur BJ. Diathermy and superficial heat, laser and cold therapy. In: Kottle, Lehmann editors. Krusen's Handbook of Physical Medicine and Rehabilitation. Philadelphia: W.B. Saunders 1990;283-6

7. Kesari KK, Siddiqui MH, Meena R, Verma HN, Kumar S. Cell phone radiation exposure on brain and associated biological systems. Indian J Exp Biol 2013;51:187-200.

8. Meltz ML. Radiofrequency exposure and mammalian cell toxicity, genotoxicity, and transformation. Bioelectromagnetics 2003;6:196-213

9. Cardinale F, Bruzzi P, Bolognesi C. Role of micronucleus test in predicting breast cancer susceptibility: a systematic review and meta-analysis. Br J Cancer 2012;106:780-90.

10. Fenech M, Denham J, Francis W, Morley A. Micronuclei in cytokinesis-blocked lymphocytes of cancer patients following fractionated partial-body radiotherapy. Int J Radiat Biol 1990;57:373-83

11. Zacher J, Carl HD, Swoboda B, Backhaus M. Imaging of osteoarthritis of the peripheral joints. Z Rheumatol 2007;66:2578.

12. Fenech $\mathrm{M}$, Holland $\mathrm{N}$, Chang WP, Zeiger $\mathrm{E}$, Bonassi S. The HUman MicroNucleus Project-An international collaborative study on the use of the micronucleus technique for measuring DNA damage in humans. Mutat Res 1999;428:271-83.

13. Balasem AN, Ali AS. Establishment of dose-response relationships between doses of Cs-137 gamma-rays and frequencies of micronuclei in human peripheral blood lymphocytes. Mutat Res 1991;259:133-8.

14. Fenech M. The cytokinesis-block micronucleus technique: a detailed description of the method and its application to genotoxicity studies in human populations. Mutat Res 1993:285:35-44

15. Pereira D, Peleteiro B, Araújo J, Branco J, Santos RA, Ramos $E$. The effect of osteoarthritis definition on prevalence and incidence estimates: a systematic review. Osteoarthritis Cartilage 2011:19:1270-85

16. Luzhna L, Kathiria P, Kovalchuk O. Micronuclei in genotoxicity assessment: from genetics to epigenetics and beyond. Front Genet 2013;4:131.

17. Lau A, Belanger CL, Winn LM. In utero and acute exposure to benzene: investigation of DNA double-strand breaks and DNA recombination in mice. Mutat Res 2009:676:74-82.

18. Iarmarcovai G, Bonassi S, Botta A, Baan RA, Orsière T. Genetic polymorphisms and micronucleus formation: a review of the literature. Mutat Res 2008;658:215-33.

19. Kirsch-Volders M, Plas G, Elhajouji A, Lukamowicz M, Gonzalez L, Vande Loock K, et al. The in vitro MN assay in 2011: origin and fate, biological significance, protocols, high throughput methodologies and toxicological relevance. Arch Toxicol 2011;85:873-99

20. Ramalho A, Sunjevaric I, Natarajan AT. Use of the frequencies of micronuclei as quantitative indicators of X-ray-induced 
chromosomal aberrations in human peripheral blood lymphocytes: comparison of two methods. Mutat Res 1988;207:141-6.

21. Zeni $O$, Romanò $M$, Perrotta $A$, Lioi $M B$, Barbieri $R$, d'Ambrosio $G$, et al. Evaluation of genotoxic effects in human peripheral blood leukocytes following an acute in vitro exposure to 900 $\mathrm{MHz}$ radiofrequency fields. Bioelectromagnetics 2005;26:25865.

22. Hansteen IL, Lågeide $\mathrm{L}$, Clausen $\mathrm{KO}$, Haugan $\mathrm{V}$, Svendsen $\mathrm{M}$, Eriksen JG, et al. Cytogenetic effects of 18.0 and $16.5 \mathrm{GHz}$ microwave radiation on human lymphocytes in vitro. Anticancer Res 2009;29:2885-92.

23. Stronati L, Testa A, Moquet J, Edwards A, Cordelli E, Villani $\mathrm{P}$, et al. $935 \mathrm{MHz}$ cellular phone radiation. An in vitro study of genotoxicity in human lymphocytes. Int J Radiat Biol 2006;82:339-46

24. Zhang M, Lu D, He J, Jin L. Effect of low-intensity microwave of on mitomycin C-induced genotoxicity in vitro. Zhonghua Lao Dong Wei Sheng Zhi Ye Bing Za Zhi 2002;20:273-6.

25. Maes A, Verschaeve L, Arroyo A, De Wagter C, Vercruyssen L. In vitro cytogenetic effects of $2450 \mathrm{MHz}$ waves on human peripheral blood lymphocytes. Bioelectromagnetics 1993;14:495501.

26. Verschaeve L. Genetic effects of radiofrequency radiation (RFR). Toxicol Appl Pharmacol 2005;207:336-41.

27. Smith DW, Clarren SK, Harvey MA. Hyperthermia as a possible teratogenic agent. J Pediatr 1978;92:878-83.

28. Lerman $Y$, Jacubovich R, Green MS. Pregnancy outcome following exposure to shortwaves among female physiotherapists in Israel. Am J Ind Med 2001;39:499-504.

29. Taskinen H, Kyyrönen P, Hemminki K. Effects of ultrasound, shortwaves, and physical exertion on pregnancy outcome in physiotherapists. J Epidemiol Community Health 1990;44:196201.

30. Ahlbom A, Green A, Kheifets L, Savitz D, Swerdlow A; ICNIRP (International Commission for Non-lonizing Radiation Protection) Standing Committee on Epidemiology. Epidemiology of health effects of radiofrequency exposure. Environ Health Perspect 2004;112:1741-54. 